\title{
The Role of the Energy Charter Treaty in Fostering and Promoting Energy Efficiency and Sustainable Development
}

\author{
Naimeh Masumy*
}

DOI: $10.21827 / 5 d 5141 c e 0 a 7 e 1$

\begin{abstract}
Keywords
ENERGY EFFICIENCY; ENVIRONMENTAL CONCERN; ACCOUNTABILITY; REGULATORY MEASURES; SUSTAINABLE DEVELOPMENT
\end{abstract}

\begin{abstract}
The paper aims to critically analyze whether the Energy Charter Treaty (hereafter "ECT") can be considered a viable instrument to foster and safeguard the concept of sustainable development, whilst simultaneously promoting foreign investment. First, an overview of the investment protection regime under ECT will be set out, assessing whether or not the ECT ensures that investments are in line with environmentally sound practices. Secondly, this study examines whether references to energy efficiency and environmental concern could signify that this treaty does not only place importance on investment protection, but also considers energy efficiency an equally important objective. Subsequently, this paper will argue that whilst the ECT can be read as promoting sustainable development, this goal is often not realized when the ECT provisions are applied in reality. Finally, the article will propose some reforms that could be made to the ECT which ensures observing key issue related to energy efficiency and sustainable development.
\end{abstract}

\section{Introduction}

The ECT provides a legal framework that creates predictability for foreign investment in developing countries. The ECT espouses predictability and non-arbitrariness (associated with the rule of law doctrine), which are cornerstones of a positive investment climate. ${ }^{1}$ The current framework of ECT provides a secure and balanced investment climate for foreign investment to grow. The purpose of this instrument was to regulate States in their investment activity, and to protect and promote foreign direct investment.

Promoting substantial rules on energy regulation arguably increases foreign investment in developing countries. ${ }^{2}$ The key aspects of this framework promote transparency, stability and predictability in investment, with appropriate contract enforcement mechanisms, allowing business to operate efficiently. ${ }^{3}$ Equally, the ECT, amongst other international regulatory instruments, promote sustainable development in

\footnotetext{
* University College London, Gower St, Bloomsbury, London WC1E 6BT, UK.

$1 \quad$ Hsu Locknie, 'Rule of Law and Foreign Investment' (2015) Rule of Law Symposium 2014: The importance of the rule of law in promoting development Research Collection School of Law 129. John Alexander, 'The Rule of Law and Foreign Direct Investment in the Developing Word' (PhD Thesis, University of California, Irvine 2014). Energy Charter Secretariat 'Role of the Energy Charter Treaty' (2009).
} 
investment activities. This ought to ensure that those affected by foreign direct investment projects benefit from sustainable practices. ${ }^{4}$ The inadequacy of the customary and international law governing States' duties in relation to alien property in developing countries prompted the international community to set minimum standards, governing States' investment activity.

The paper examines whether or not the ECT has, in reality, promoted sustainable development in investment practice. While the paper does not make a claim regarding the legal status of the principle of sustainable development, it will scrutinize whether the current articulation and reference of SD in the ECT effectively promotes the components of sustainable development.

\section{Genesis and Objectives of the ECT}

This section briefly remarks on the genesis and objectives of the ECT. The legal protection regime set out in the ECT will be discussed. The investment protection regime enshrined in the ECT framework offers extensive protection against the risk of regulatory changes; however, certain aspects of the ECT are weighted more so in favour of investor interests over State interests and the principle of sustainable development.

\section{The Energy Charter Treaty's Principles and Objectives}

The ECT is a unique multilateral treaty which was designed to unite the Former Soviet Countries with the rest of Europe by forming a common ground for foreign energy investment practice. ${ }^{5}$ It aimed to create long-term cooperation between the former Soviet countries and European countries. ${ }^{6}$ Former Soviet countries were oil-rich but economically impoverished, and therefore in dire need of capital investment to bolster their economic growth. ${ }^{7}$ The end of the cold war granted an unprecedented opportunity to European countries to forge stronger economic bonds with Russia and its neighboring countries to support those States in their transition to market economies. ${ }^{8}$ Hence, The ECT has retained a distinctively European flavor and the provisions enshrined in the treaty have their roots in investment liberalization. ${ }^{9}$ Some scholars have even argued that the far-reaching investment protection regime contained in the ECT demonstrates how this regime was set out predominantly to protect the European countries' outward investment. ${ }^{10}$

4 Adebola Adeyemi, 'Changing the Face of Sustainable Development in Developing Countries: The role of the International Finance Corporation' (2014) 16(2) Environmental Law Review 208.

5 Gerard Hafner, 'The 'Provisional Application' of the Energy Charter Treaty' in Christina Binder and others (eds), International Investment Law for the 21 st Century (Oxford Scholarship 2009) 599.

$6 \quad$ Lucy Reed, 'The Energy Charter Treaty: An Overview' (2008) 14 (2) Journal of International and Comparative Law 405,440.

7 ibid 408.

8 Emmanuel Gaillard and Mark McNeill 'The Energy Charter Treaty' in Katia Yannaca-Small (ed), Arbitration Under International Investment Agreements (Oxford University Press 2010) 44.

$9 \quad$ R J Stevenson, 'Energy Charter Treaty: Implications for Australia' (2001) 19(2) Journal of Energy \& Natural Resources Law 116.

10 Regina S Axelrod, 'The European Energy Charter Treaty: Reality or Illusion?' (1996) 24(6) Energy Policy 497, 499. 
The ECT focuses principally on the characterization of energy investment, ${ }^{11}$ which makes this instrument markedly different from other treaties or bilateral agreements formed to protect and promote foreign investment. Article 2 of the ECT encapsulates the central theme of the treaty where it is explained that the treaty was formed "[...] to promote the longterm cooperation in the energy field, [...] in accordance with the objectives and principles of the Charter". ${ }^{12}$

There are a number of objectives associated with the ECT; the most important one, which is claimed to be the cornerstone of the treaty, is the legal protection of foreign energy investment. ${ }^{13}$ In light of this regime, the ECT's provisions on investment issues attempt to ensure the creation of a "level playing field" for energy sector investments throughout the Charter, with the aim of reducing to a minimum the non-commercial risks associated with energy-sector investment in foreign countries such as discrimination, nationalization, damages due to war etc. The ECT's deference to the principle of State sovereignty is enshrined in Article 18, 'Sovereignty over State Resources', wherein it is stated: "(1) The Contracting Parties recognize State sovereignty and sovereign rights over energy resources. ${ }^{14}$ They reaffirm that the State sovereignty "must be exercised in accordance with and subject to the rules of international law." ${ }^{15}$ It attempts to balance the desire of investors for extensive protection mechanisms and the need of the State to acknowledge its sovereignty over its natural resources and its discretion to regulate as it sees fit.

However, whether or not the inclusion of the principle of State sovereignty in Article 18 introduces real obligations on investors remains unclear. This paper will further scrutinize in the next section whether or not Article 18 has struck the optimum balance between investor protection and the principle of State sovereignty. In addition, the promotion of sustainable development is another agenda that ECT pursues. ${ }^{16}$ It must be noted that the aim of promoting efficient energy and heightened environmental practices is well-grounded in the original intention of the treaty. ${ }^{17}$ References to energy efficiency and environmental concerns signify that this treaty does not only place importance on investment protection, but also considers energy efficiency an equally important objective. ${ }^{18}$ Crucially, the issue on climate change has been included in the treaty's preamble. This reference in the preamble indicates that the ECT at the time of its creation was wary of the implications of energy investment on

\footnotetext{
11 Richard Happ, 'Dispute Settlement under the Energy Charter Treaty' (2002) 45 German Yearbook of International Law 331, 339.

12 The Energy Charter Treaty (Lisbon, 17 December 1994) 2080 UNTS 95, art 2.

13 Kaj Hober 'Investment Arbitration and the Energy Charter Treaty' (2010) 1 International Dispute Settlement 153,155.

$14 \quad$ Energy Charter Treaty (n 12) art 18(1).

15 Secretariat's statement on the principle of state sovereignty (7 June 2000) $<$ http:// www.encharter.org/English/Secretrait/index.htm>17 June 2000.

16 Sheng Zhang, 'The Energy Charter Treaty and China: Member of Bystander' (2012) 13(4) Journal of World Investment 597, 600 .

17 ibid 598.

18 Edna Sussman, 'The Energy Charter Treaty's Investor Protection Provisions: Potential to Foster Solutions to Global Warning and Promote Sustainable Development' (2008) 14 Journal of International and Comparative Law 391.
} 
the environment. ${ }^{19}$ It could also be argued that the inclusion of the Energy Charter Protocol on Energy Efficiency and Related Environmental Aspects suggests that the treaty's environmental agenda is not devoid of any meaning, nor does the ECT pay mere lip service to the concept of sustainable development. This principle requires States to formulate a clear policy for improving energy consumption and productions and reducing negative energy cycles. ${ }^{20}$ Article 19 of the ECT in the pursuit of sustainable development and taking into account its obligations under those international agreements concerning the environment to which it is party - each Contracting Party shall strive to minimize in an economically efficient manner harmful Environmental Impacts. ${ }^{21}$ Therefore, it can be argued that the ECT serves an important role in ensuring that investments are in line with environmentally sound practices. However, as it will be discussed in the next section, whilst the ECT can be read as promoting sustainable development, this goal is often not realized when the ECT provisions are applied in reality.

\section{The Lack of Specification of the State Sovereignty Principle in the ECT} Article 18 (1) enshrines the principle of state sovereignty over the use of energy resources in the ECT. This principle aims to allow a state to fully or partially regulate its energy resources as it sees fit. ${ }^{22}$ The subsequent provisions of Article 18 elaborate upon some of the specifications of this principle. Article 18(2) provides that the Treaty shall not prejudice Contracting Parties, or the rules governing their systems of property ownership and energy resources. ${ }^{23}$ Article $18(4)$ provides that each State continues to hold the right to decide the geographical areas to be made available for exploration and development of its energy resources and the rate at which they may be depleted or otherwise exploited. ${ }^{24}$

The open-textured nature of Article 18 has led some scholars to question whether or not the invocation of this principle is practically possible or even conceptually plausible under the treaty. ${ }^{25}$ The lack of a clear formulation of this principle means that State sovereignty lacks any real force, practically speaking.

The provision proves difficult to read alongside other provisions, such as Article 10(1). It appears to be declaratory of general international law principles, and it does not clearly define how a State can derogate from its obligations enumerated in earlier parts of the treaty. It seems to outline the inherent right to legislate issues related to public policy ${ }^{26}$ however, it is not explained how this should apply in reality. The subsequent statement of the ECT secretariat in which he specified that "this right must be exercised subject to the rules of

\footnotetext{
19 ibid 395.

20 Andrei Konoplyanki and Thomas Waelde, 'Energy Charter Treaty and its Role in International Energy' (2006) 24(4) Journal of Energy and Natural Resources Law, 523, 535.

21 Energy Charter Treaty (n 12) art 10.

22 Yogesh Tyagi, 'Permanent Sovereignty over Natural Resources' (2015) 4(3) Cambridge Journal of International and Comparative Law 588, 590.

23 Energy Charter Treaty (n 12) art 18(2).

$24 \quad$ Energy Charter Treaty (n 12) art 18(4).

25 D E Fisher, "The Meaning and Significance of Resource Security" in A Gardner (ed), The Challenge of Resource Security: Law and Policy (The Federation Press, Sydney, 1993) 16.

26 Secretariat's Statement on the Principle of State Sovereignty (n 15).
} 
The Role of the Energy Charter Treaty in Fostering and

Promoting Energy Efficiency and Sustainable Development

international law"27 failed to shed light on what would be the clear scope of this principle's application. Essentially, the treaty does not specifically address - in the event of conflict between the expropriation measures defined in Article 10 and the State sovereignty principle in Article 18 - which notion would trump. ${ }^{28}$

\section{III.I The Importance of the Principle of Sovereignty in Ensuring Sustainable use of Natural Resources}

The principle of sovereignty is a well-established principle, based in international law. This principle implies that States have a wide discretion to manage their own natural resources. Further, as McCaffrey would argue, the principle also dictates that States are under the duty to manage natural resources within their own jurisdiction in a sustainable and effective way, so as to conserve natural resources appropriately. ${ }^{29}$ This author would argue that the lack of specification in international law as to the scope of State sovereignty has significantly undermined the pursuit of sustainable development goals, when balanced against the aim of increasing foreign investment. In addition, the ECT does not impose any obligation on States to manage their natural resources in "a rational, sustainable and safe way as to contribute to the development of their peoples." ${ }^{30}$ In fact, the ECT is generally hesitant towards the quality or potential negative effects of FDI. More importantly, it can be argued that the ECT regulatory scheme does not grant States the discretion to determine the investment as being unsustainable based on any specific qualitative or quantitative criteria. This constitutes a major pitfall of the ECT regime in fostering and promoting the notion of sustainable development.

\section{The Neglect of the Concept of Sustainable Development in International Law}

The issue of the sustainable development has now been situated on the forefront of the energy discourse. ${ }^{31} \mathrm{New}$ international instruments attempt to embody this concept within their structures in order to be more responsive to the contemporary needs of the energy market. ${ }^{32}$ The energy market is rapidly evolving, and there is a radical shift in the approach of energy production and consumption. The concept of sustainable development has been incorporated into many international legal documents and has captured some of these changes within the energy market. However, the ECT fails to attend to such non-commercial interests making the instrument unable to respond to the needs of the market. There is a cursory reference to the concept of the sustainable development within the ECT which has rendered it devoid of any real meaning.

\footnotetext{
27 ibid.

28 Tania Voon and Andrew Mitchell, 'Denunciation, Termination and Survival: The interplay of Treaty Law and International Investment Law' (2016) 31(2) ICSID Review 413.

29 Stephen C. McCaffrey, 'Keynote: Sustainability and Sovereignty in the 21st Century' (2013) 41 Denv J Int'1 L \& Poly 507.

30 UNGA, Agenda 21 (14 June 1992 Rio de Janeiro) UN Doc A/CONF.151/26.

31 Sussman (n 18) 402-404.

32 Daniel Esty, 'Integrating Trade and Environmental Policy Making: First Step in the NAFTA' in Druwood Zaelke (ed) Trade and Environment: Law, Economics and Policy (Island Press 1993) 50.
} 
As discussed earlier, the ECT regime creates favourable conditions by imposing binding obligations on States with respect to their treatment of foreign investment. To this end, a wide asset-based definition of investment was adopted in this framework. ${ }^{33}$ The term "investment" is envisioned in Article 1(6) which encompasses every kind of asset, owned or controlled directly or indirectly by an investor and includes: (a) tangible and intangible, and movable and immovable, property, and any property rights such as leases, mortgages, liens, and pledges. ${ }^{34}$ This definition under the ECT is essentially a broad and open-ended list of every conceivable right or interest connected with investments. ${ }^{35}$ The only limiting factor contained within the definition is that an investment ought to be closely related to an "Economic Activity in the Energy Sector". ${ }^{36}$ However, the association with such activity and the necessary degree of such association that must exist for a dispute to fall under the ECT dispute mechanism is not yet clearly articulated. ${ }^{37}$

The tribunals in the Yokus $^{38}$ arbitration read Article 1(6) (b) of the ECT as containing the widest possible definition of an interest in a company with no indication that the drafters of the ECT intended to limit ownership to "beneficial" ownership. In Petrobart limited $V$ the Kyrgyz Republic, ${ }^{39}$ the tribunal considered that the claimant's claim for payment under an ordinary sales agreement for gas condensate constituted an "investment" within the meaning of article 1(6) (f).

This broad and commercially oriented definition does not include nor specify any qualitative criteria, nor refer to any social purpose of the investment in question. ${ }^{40}$ It can be argued that the ECT fails to encompass the notion of sustainable development by including whether or not the investment in question is environmentally or socially destructive. In essence, based on the current articulation of the ECT regime, a given investment is not disqualified from the benefits of the ECT protection if it fails to meet sustainability criteria.

However, this author acknowledges that making distinctions between sustainable investments and unsustainable investments is a task to be borne by States rather than international instruments. It is evident that making determinations with respect to the sustainability of investments is fraught with conceptual uncertainty. It is suggested that there is no legal consensus on how various components of sustainable development can be optimally balanced and exercised. Provided that investments are invariably contextual and project specific, one is unable to strike an optimal balance between economic, environmental and social impacts of large investments in any legislation. A subjective assessment as to the sustainability of a given investment is required. Devising qualifying criteria to ascertain the

33

Andre Newcombe, 'Sustainable Development and Investment Treaty Law' (2007) 8. J World Investment \& Trade 357, 364.

Energy Charter Treaty (n 12) art 1(6).

Kaj Hober, 'The Energy Charter Treaty- Award Rendered' (2007) 1(1) Dispute Resolution International 36, 50.

ibid 42.

Happ, (n 11) 341.

Yukos Universal Limited (Isle of Man) v. The Russian Federation, UNCITRAL, PCA Case No. AA 227 (30 November 2009).

Petrobart Limited $v$ The Kyrgyz Republic, SCC Case No. 126/2003, para 12.

Kaj Hober, The Energy Charter Treaty - Chapter5- Investment Arbitration In Eastern Europe: In Search of A Definition of Expropriation (Juris Arbitration Law 2007). 
The Role of the Energy Charter Treaty in Fostering and

Promoting Energy Efficiency and Sustainable Development

sustainability of one given investment would amount to significant uncertainty and potential unfairness.

\section{IV.I The Significance of Reconceptualization of Sustainable Development Within the Treaty}

The future drafters of the treaty should be mindful that the cursory reference to the concept of sustainable development undermines sustainable development as a legal norm; it becomes more of an aspirational notion, devoid of any legal effect. No clear delineation exists as to what constitutes criteria for sustainable development at present within the ECT. It appears that the ECT adopted a formulation of sustainable development based on a reconciliation between economic growth and environmental protection, as opposed to a stand-alone concept in and of itself. ${ }^{41}$

The ECT regime failed to delineate what constitutes sustainable development. Reference to the three components of sustainable development - economic development, social development and environmental protection - as interdependent and mutually reinforcing concepts ${ }^{42}$ would go some way to remedy this deficiency. As suggested by Duncan French, a leading scholar in the field of sustainable development, a new conceptualization of sustainable development is required within the ECT framework. Future revisions of the ECT should reflect and acknowledge the three main subsidiary principles by including social, economic and environmental impact assessments of any specific investment project, to be assessed at a local level. ${ }^{43}$ This new pragmatic reconceptualization of sustainable development, by contextualizing it in the form of social, economic and environment impact assessments, overcomes the conceptual difficulties associated with defining what constitutes sustainable development. This articulation gives the concept force, and provides local and affected groups with the authority to balance environmental, economic and social concerns against the goal of increasing foreign investment in a particular area.

IV.II Propositions to Streamline the Sustainable Development Process As Thomas Waelde and Stephen Dow assert, there is a need to incorporate innovative investment promotion to stimulate investment specifically geared towards sustainable development goals. ${ }^{44}$ Environmental protection is stipulated in terms of the ECT. ${ }^{45}$ There is no friction or conflict between the investment protection regime and sustainable development goals. This author would argue that the ECT could be used to promote environmental concerns consistent with the sustainable development agenda. While the ECT is cognizant of its broader position within the international realm to promote energy efficiency and

41

The Gabcikovo-Nagymaros Project (Hungary/Slovakia) (Judgement) [1997] ICJ Rep, para 140.

Plan of Implementation of the World Summit on Sustainable Development adopted at World Summit of Sustainable Development (4 September 2002 Johannesburg) UN Doc/Conf.199/20 (2002) para 4. Duncan French, International Law and Policy of Sustainable Development (Manchester University Press 2005) 22.

Craig Bamberger and Thomas Waelde, 'The Energy Charter Treaty', Energy law in Europe: national, EU and international law and institutions (Oxford University Press 2001) 57.

Jan McDonald, 'The Multilateral Agreement on Investment: Heyday or Mal day for Ecologically Sustainable Development?' (1998) 22 Melbourne University Law Review 617, 624. 
sustainable development, ${ }^{46}$ this treaty has not been effective in developing the decisions on how the energy must be produced and developed in consistent with the sustainable development agenda. A number of steps could be taken to ensure the smooth operation of the concept of sustainable development.

The following measures are proposed by this author to help the application of sustainable development goals to the ECT regime.

A) Instead of setting out objective criteria to gauge the sustainable nature of investments, the ECT regime could establish sustainability impact assessments. Any given investment must undergo this assessment prior to qualifying for the benefits contained in ECT. This process can include, for example, avoiding wasteful use of natural resources and promoting efficient waste minimization policies. Muchlinski's writings suggest that the best way to guarantee that States comply with the results of such assessments is to impose specific contractual obligations on States. ${ }^{47}$

B) The ECT ought to impose more onerous reporting requirements on investors. This could constitute reporting guidelines on economic, environmental and social performance of any given investment. The reporting system could operate prior to any investment being made and the reporting could be designed to monitor the social and environmental performance aspects of one investment. If the reporting requirement is not met to a satisfactory standard, then the host States will have the discretion to impose fines on investors or revoke their right to continue with the investment project.

C) The ECT could introduce a new framework for investor conduct that is consistent with the principle of sustainable development. The ECT arguably reinforces what is acceptable, with respect to the conduct of investors. The ECT could expressly include best practice norms, standards and guidelines in the treaty text. If investors violated the standards contained in the provisions, a host State could institute proceedings to have the investors' rights abrogated.

\section{Conclusion}

As it stands, the ECT regime does not impair the concept of sustainable development. Indeed, aspects of the ECT framework actively promote sustainable development. The ECT is problematic, however, in that it only partially integrates the concept of sustainable development. The ECT lacks specification as to how to best promote sustainable development in practice. If the regime were to be revised, this author would argue for the integration of sustainable development principles by clearly delineating the scope of investment obligations and providing consistent and coherent mechanisms to promote sustainable development. The above suggestions highlight how the concept of sustainable development can have real effect through an incorporation in the treaty of impact assessments, reporting requirements and a code of conduct for investors. The ECT should refer to all aspects of sustainable development - social, economic and environmental. Social development, in particular, should be referred to in future drafts of the treaty; as a concept, it includes good governance, respect for human rights and the promotion of human health. Future treaty drafters should be mindful of evolving international standards in order to a treaty optimal for the sustainable development agenda.

Sussman (n 18) 392.

47 Peter T Muchlinski, Multinational Enterprises and the Law (Oxford University Press 1995). 
The Role of the Energy Charter Treaty in Fostering and Promoting Energy Efficiency and Sustainable Development

www.grojil.org 